J. Reprod. Fert. (1971) 27, 339-347

\title{
LOSS OF SPERMATOZOA FROM THE REPRODUCTIVE TRACT OF THE EWE AND INTENSIFICATION OF SPERM 'BREAKAGE' BY PROGESTAGEN
}

\author{
H. W. HAWK AND H. H. CONLEY \\ United States Department of Agriculture, ARS Animal Science Research Division, \\ Agriculture Research Center, Beltsville, Maryland 20705, U.S.A.
}

(Received 2nd December 1970)

Summary. Sponges impregnated with medroxyprogesterone acetate (MAP) were left in the vaginae of parous ewes from 8 to 25 days after oestrus. The ewes were inseminated with $0.25 \mathrm{ml}$ of fresh ram semen 45 $\mathrm{hr}$ after removal of the sponges. Ewes in natural oestrus were inseminated as controls. In half of the ewes of each group, the reproductive tract was ligated at the vulvovaginal junction at the time of insemination to prevent the loss of sperm cells by drainage. Ewes were killed $24 \mathrm{hr}$ after insemination and the number of spermatozoa in each segment of the reproductive tract was estimated.

While $62 \%$ of the spermatozoa were recovered from ewes in which the vulvovaginal junction was ligated, less than $1 \%$ were recovered from the ewes with unligated tracts, indicating the loss of large numbers of sperm cells by drainage. Fewer spermatozoa and a higher proportion of tailless sperm heads were recovered from ewes treated with MAP than from control ewes.

\section{INTRODUCTION}

Large numbers of sperm cells disappear from the female reproductive tract within the first few hours of mating (First, Short, Peters \& Stratman, 1968, for sows; Quinlivan \& Robinson, 1969, for ewes). Greater numbers of sperm cells remained in the tract after artificial insemination of ewes in natural oestrus than after artificial insemination following the use of progestagen-impregnated intravaginal sponges (Quinlivan \& Robinson, 1969). The low number of spermatozoa in the oviducts of some ewes after use of the intravaginal sponge was believed to be the cause of lowered ovum fertilization rates (Quinlivan \& Robinson, 1967).

Sperm cells are presumably lost from the female reproductive tract by drainage to the exterior or by phagocytosis or disintegration within the tract. This experiment was conducted to determine whether drainage could be implicated as a major cause of sperm cell loss after artificial insemination, and to identify some of the changes occurring in sperm cell loss after the use of progestagen-impregnated sponges. 


\section{MATERIALS AND METHODS}

The ewes were parous Rambouillets, about 8 years of age. They were checked twice daily for oestrus by the use of vasectomized rams, the lst day of oestrus being designated as Day 0 of each cycle. On Day 8 of a cycle, a cylindrical sponge $2 \mathrm{~cm}$ in diameter and $8 \mathrm{~cm}$ long, impregnated with $60 \mathrm{mg}$ of medroxyprogesterone acetate (MAP, The Upjohn Company), was inserted into the anterior portion of the vagina of each of twenty-two ewes (Tables 1 and 2). After 16 to 18 days, i.e. 24 to 26 days after oestrus, the sponges were removed. The ewes were artificially inseminated $45 \mathrm{hr}$ later, fourteen of the twenty-two ewes being in oestrus; the eight ewes that were not in oestrus were inseminated because some ewes do not show oestrus in conjunction with regulated ovulation (Robinson, Moore, Holst \& Smith, 1967). No more than two of these eight ewes fell into any experimental group in Table 1 and no more than three fell

\section{TABLE 1}

EFFEGT OF REGULATION OF THE OESTROUS CYCLE AND LIGATION OF THE VULVOVAGINAL JUNGTION ON THE NUMBER OF SPERMATOZOA RECOVERED FROM THE VAGINA 5 HR AFTER INSEMINATION*

\begin{tabular}{l|c|c|c|c|c}
\hline \multirow{2}{*}{$\begin{array}{c}\text { Group and } \\
\text { type of } \\
\text { oestrus }\end{array}$} & $\begin{array}{c}\text { Vulvo- } \\
\text { vaginal } \\
\text { junction }\end{array}$ & $\begin{array}{c}\text { No. } \\
\text { of } \\
\text { ewes }\end{array}$ & \multicolumn{2}{|c|}{ No. of spermatozoa recovered $\times 10^{6}$} \\
\cline { 3 - 5 } & Intact & Tailless & Total \\
\hline 1. Cyclic & Open & 3 & $3 \cdot 2$ & $0 \cdot 2$ & $3 \cdot 4$ \\
2. Regulated & Open & 3 & $1 \cdot 6$ & $0 \cdot 4$ & $2 \cdot 0$ \\
3. Cyclic & Closed $\dagger$ & 3 & $8 \cdot 7$ & $1 \cdot 2$ & $9 \cdot 9$ \\
4. Regulated & Closed $\dagger$ & 3 & $0 \cdot 6$ & $6 \cdot 8$ & $7 \cdot 4$ \\
\hline
\end{tabular}

* Ewes were inseminated in the cervical os with an average of $25 \times 10^{6}$ spermatozoa.

$\dagger$ The vulvovaginal junction was ligated at the time of insemination.

into any group in Table 2 ; these ewes had either ovulated or were near ovulation when killed, resembling ewes that were bred while in oestrus. Control ewes had no sponges in the vagina and were inseminated on the 1st day of oestrus.

All ewes were inseminated with $0.25 \mathrm{ml}$ of semen taken from pooled ejaculates of two rams. The semen was collected in an artificial vagina and used for insemination within 30 min. The semen had good motility and less than $2 \%$ of the sperm cells were 'broken' into heads and tails; $0.25 \mathrm{ml}$ of the semen contained an average of $536 \times 10^{6}$ sperm cells.

The vulvovaginal junction was ligated in twenty-two ewes (Tables 1 and 2). The tissue around the junction was anaesthetized locally by injections of a solution of $2 \%$ procaine. The vulva was held open by forceps and a ligature was placed in the mucosa at the vulvovaginal junction. Particular care was taken not to puncture or occlude the urethra. The insemination tube was then positioned against the cervical os, the ligature tightened around the insemination tube, and the semen expelled. The ligature was tightened and tied as the tube was withdrawn. The ewes in which the reproductive tract was left open 
were inseminated in the same way except that no anaesthetic or vulvovaginal ligature was used.

In an initial experiment (Table 1), ewes were killed $5 \mathrm{hr}$ after insemination, but in the main experiment (Table 2), they were killed $24 \mathrm{hr}$ after insemination. The entire reproductive tract was removed immediately after the death of each ewe. Haemostatic forceps were clamped on the tract at the tubo-uterine junctions and the junction of the uterus and cervix. Each oviduct and uterine

TABle 2

EFFECT OF REGULATION OF THE OESTROUS CYCLE AND LIGATION OF THE VULVOVAGINAL JUNGTION ON THE MEAN NUMBER OF SPERMATOZOA RECOVERED FROM THE REPRODUGTIVE TRAGT 24 HR AFTER INSEMINATION*

\begin{tabular}{|c|c|c|c|c|c|}
\hline $\begin{array}{l}\text { Group, type } \\
\text { of oestrus and } \\
\text { portion of the } \\
\text { reproductive } \\
\text { tract }\end{array}$ & $\begin{array}{l}\text { Vulvo- } \\
\text { vaginal } \\
\text { junction }\end{array}$ & $\begin{array}{l}\text { No. } \\
\text { of } \\
\text { ewes }\end{array}$ & $\begin{array}{l}\text { Intact } \\
\text { sperm. } \\
\text { recovered } \\
\left(\times 10^{3}\right)\end{array}$ & $\begin{array}{l}\text { Tailless } \\
\text { sperm. } \\
\text { recovered } \\
\left(\times 10^{3}\right)\end{array}$ & $\begin{array}{l}\text { Total } \\
\text { sperm. } \\
\text { recovered } \\
\left(\times 10^{3}\right)\end{array}$ \\
\hline $\begin{array}{l}\text { 1. Cyclic } \\
\text { Vagina } \\
\text { Cervix } \\
\text { Uterus } \\
\text { Oviduct }\end{array}$ & Open & 8 & $\begin{array}{rr}1085 & (7) \dagger \\
188 & (7) \\
9 \cdot 4 & (6) \\
1 \cdot 9 & (6)\end{array}$ & $\begin{array}{rr}1312 & (7) \\
51 & (5) \\
1 \cdot 6 & (5) \\
0.2 & (5)\end{array}$ & $\begin{array}{rr}2397 & (7) \\
239 & (7) \\
11 \cdot 0 & (6) \\
2 \cdot 1 & (6)\end{array}$ \\
\hline $\begin{array}{l}\text { 2. Regulated } \\
\text { Vagina } \\
\text { Cervix } \\
\text { Uterus } \\
\text { Oviduct }\end{array}$ & Open & 8 & $\begin{array}{cc}9 & (2) \\
12 & (3) \\
3 \cdot 7 & (4) \\
0.5 & (3)\end{array}$ & $\begin{array}{cc}50 & (3) \\
8 & (3) \\
0 \cdot 7 & (6) \\
0.4 & (5)\end{array}$ & $\begin{array}{ll}59 & (4) \\
20 & (5) \\
4 \cdot 4 & (6) \\
0.9 & (5)\end{array}$ \\
\hline $\begin{array}{l}\text { 3. Cyclic } \\
\text { Vagina } \\
\text { Cervix } \\
\text { Uterus } \\
\text { Oviduct }\end{array}$ & Closed $\ddagger$ & 8 & $\begin{array}{rr}272,000 & (8) \\
5966 & (8) \\
129.5 & (6) \\
0.6 & (3)\end{array}$ & $\begin{array}{rr}46,000 & (8) \\
481 & (8) \\
6 \cdot 1 & (5) \\
0 \cdot 3 & (3)\end{array}$ & $\begin{array}{rr}318,000 & (8) \\
6448 & (8) \\
135.7 & (7) \\
0.9 & (4)\end{array}$ \\
\hline $\begin{array}{l}\text { 4. Regulated } \\
\text { Vagina } \\
\text { Cervix } \\
\text { Uterus } \\
\text { Oviduct }\end{array}$ & Closed $\ddagger$ & 8 & $\begin{array}{rr}59,000 & (6) \\
51 & (4) \\
1 \cdot 4 & (4) \\
0.3 & (2)\end{array}$ & $\begin{array}{rr}283,000 & (8) \\
1629 & (7) \\
1 \cdot 3 & (6) \\
0.0 & (0)\end{array}$ & $\begin{array}{rr}341,000 & (8) \\
1680 & (7) \\
2 \cdot 7 & (7) \\
0.3 & (2)\end{array}$ \\
\hline
\end{tabular}

* Ewes were inseminated against the external cervical os with an average of $536 \times 10^{6}$ spermatozoa.

$\dagger$ The means were calculated on the basis of eight ewes per group, with 'zero' being used in cases where no spermatozoa were recovered. The figures in parentheses are the number of ewes in the group from which spermatozoa were recovered.

$\ddagger$ The vulvovaginal junction was ligated at the time of insemination.

horn and the uterine body, cervix and vagina were dissected free of connective tissue and flushed separately with saline solution $(0.9 \% \mathrm{NaCl})$. The oviducts were each flushed with $10 \mathrm{ml}$ of solution. Each uterine horn was clamped at either end, injected with about $15 \mathrm{ml}$ of saline solution, manipulated vigorously to suspend sperm cells in the solution, drained of its contents, and flushed repeatedly to a total volume of $50 \mathrm{ml}$. The uterine body was washed with $10 \mathrm{ml}$ of saline solution. Flushings from the uterine horns and body were pooled. The lumen of the cervix was flushed with $10 \mathrm{ml}$ of solution, then the cervix was opened lengthwise and stored overnight in saline solution at $4^{\circ} \mathrm{C}$ to loosen spermatozoa remaining in the cervical crypts. The saline was shaken vigorously 
before the cervix was removed. The vagina was flushed thoroughly with $50 \mathrm{ml}$ of saline solution.

The flushings were stored overnight at $4^{\circ} \mathrm{C}$, then adjusted to the desired volume by centrifugation or dilution. The resulting samples were mixed well and aliquots placed in leucocyte counting chambers $0.2 \mathrm{~mm}$ deep. At least 20 min were allowed for spermatozoa to settle to the floor of the chamber, then intact sperm cells and tailless sperm heads were counted at $\times 200$ with a phase contrast microscope and the numbers of intact and tailless sperm cells flushed from each segment of the tract were calculated.

The data were transformed to log numbers for statistical analysis. Statistical comparisons were made by analyses of variance and by $t$ tests. In the second experiment, when spermatozoa were not always found in the flushings of a segment of the tract, the following log numbers were used as sham values for statistical analyses where no intact, tailless or total spermatozoa were found in the segment of the tract: vagina, 3.30 ; cervix, $3 \cdot 18$; uterus, 2.30 ; oviducts, 1.30. The sham logs represent numbers which were half of the lowest number of spermatozoa that would have been detected. The means in Tables 1 and 2 were calculated from the actual numbers of spermatozoa counted, with zero being used in cases where no spermatozoa were found.

The ratios of intact to tailless spermatozoa were analysed statistically by subtracting the log number of tailless from the log number of intact spermatozoa for the particular segment of tract within each sheep. The resulting numbers were compared between groups by $t$ test.

In the following text, the term 'sperm breakage' indicates the disconnection of the sperm midpiece from the head. 'Cyclic' refers to control ewes or to oestrus in the control ewes; 'regulated' refers to the ewes or to oestrus in the ewes in which MAP sponges were used to regulate ovulation.

\section{RESULTS}

\section{Experiment 1}

Ligation of the vulvovaginal junction at the time of insemination greatly increased the total number of spermatozoa recovered from the vagina (Table 1; $P<0.001$ for Groups 1 and 2 versus 3 and 4). Regulation of oestrus significantly decreased the number of intact spermatozoa recovered from the vagina $(P<0.05$ for Groups 1 and 3 versus 2 and 4$)$. Regulation of oestrus also increased the ratio of tailless to intact spermatozoa $(P<0.025)$. Trends similar to these, but less pronounced, were seen in other sections of the reproductive tract. The results suggested that ligating the vulvovaginal junction prevented the drainage of large numbers of spermatozoa to the exterior and that regulation of oestrus resulted, at least in the vagina, in greater breakage of sperm cells into heads and tails.

\section{Experiment 2}

The ewes were killed $24 \mathrm{hr}$ after insemination. Fourteen of the sixteen cyclic ewes and ten of the sixteen regulated ewes had ovulated before autopsy. It is likely that, on the average, the regulated ewes were inseminated slightly earlier 
in relation to ovulation than were the cyclic ewes. Five ewes that had ovulated fell into each group of eight regulated ewes.

Effect of ligation. Ligating the vulvovaginal junction increased the number of sperm cells recovered from the vagina (Table 2, Groups 1 and 2 versus 3 and 4; $P<0.001$ for intact, tailless and total spermatozoa). Ligation also increased the number of spermatozoa recovered from the cervices $(P<0.05$ for intact spermatozoa; $P<0.001$ for tailless and for total spermatozoa). Despite the fact that the ewes with ligated tracts had greater numbers of sperm cells in their cervices and vaginae, these ewes had somewhat smaller numbers of spermatozoa in their oviducts than were found in the oviducts of ewes with open tracts.

Effect of regulating oestrus. The data were analysed separately for ewes with open and with closed tracts because of the possible effect of ligation on sperm transport. Significantly fewer intact spermatozoa were recovered from vaginae of regulated than of cyclic ewes (Table 2; $P<0.005$ for ewes with open tracts, Group 1 versus Group 2; $P<0.01$ for ewes with closed tracts, Group 3 versus Group 4). For the cervices also, the numbers of intact spermatozoa were significantly lower for the regulated ewes $(P<0.01$ for ewes with open tracts; $P<0.001$ for ewes with closed tracts). Similarly, the numbers of intact spermatozoa recovered from the uterus and oviducts tended to be lower in the regulated ewes.

The number of tailless sperm heads recovered from the vaginae of ewes with closed tracts was significantly higher for regulated than for cyclic ewes $(P<0 \cdot 005$, Group 3 versus Group 4$)$. In the ewes with open tracts (Groups 1 and 2), the number of tailless spermatozoa recovered from the vaginae was higher for the cyclic ewes $(P<0.01)$, this difference probably being caused by the fact that more spermatozoa remained in the vaginae of the cyclic ewes and were thus available to be broken.

The ratio of tailless to intact spermatozoa was generally higher in regulated than in cyclic ewes, the difference being particularly noticeable in the ewes with closed tracts $(P<0.001$ for the vaginae of ewes with closed tracts; $P<0.01$ for cervices of ewes with closed tracts; $P=0 \cdot 10$ for the vaginae of ewes with open tracts). The retention of large numbers of sperm cells in the lower segments of the closed tracts presumably allowed the sperm-breaking capacity of the tracts of regulated ewes to be made evident.

\section{DISGUSSION}

The recovery of fewer sperm cells from the open reproductive tracts of regulated than of cyclic ewes agrees with data of Quinlivan \& Robinson (1969). The points shown in the present work which have not been reported previously are the large losses of spermatozoa by drainage, the magnitude of potential losses within the reproductive tract, and the intensification of sperm cell breakage by the use of progestagen-impregnated sponges.

\section{Sperm cell losses by drainage, breakage and disappearance}

The data in Table 2 provide a rough indication of the potential losses of sperm cells by drainage to the exterior or by destruction within the reproductive 
tract. It is likely that the loss of sperm cells through the oviducts and into the body cavity is negligible. Therefore, the sperm cells deposited in ligated reproductive tracts that were not recovered as intact cells or as tailless heads had presumably been destroyed within the tracts. From ewes with ligated tracts, the total number of spermatozoa recovered averaged about $330 \times 10^{6}$ (Groups 3 and 4, Table 2), indicating that an average of about $205 \times 10^{6}$ sperm cells had disappeared within the ligated tracts. For the ewes with open tracts (Groups I and 2), more than $99 \%$ of the spermatozoa deposited in the tract had been lost, including almost all of the $330 \times 10^{6}$ spermatozoa that were counted in the flushings from ewes with ligated tracts; it might, therefore, be assumed that at least $330 \times 10^{6}$ spermatozoa, about $62 \%$ of those deposited in the cervical os, had been lost by drainage from the open tracts. This figure probably underestimates the loss by drainage because it is doubtful if as many as $205 \times 10^{6}$ sperm cells remained in the open tracts to be destroyed there. It is more likely that over $62 \%$ of the spermatozoa deposited in the ewes with open tracts was lost by drainage. Quinlivan \& Robinson (1969) found that most of $500 \times 10^{6}$ sperm cells deposited in the cervices of ewes had been lost within $1 \mathrm{hr}$, which suggests rapid loss by drainage.

It is not certain how many of the spermatozoa that 'disappeared' within the reproductive tract were phagocytosed. Only limited numbers of phagocytosed sperm cells were seen under the phase microscope, these cells being recognized by the protrusion of their tails from leucocytes. However, the entire sperm cell can be phagocytosed and its refractile nature is lost inside the leucocyte within a few minutes (Reid, 1965). Large numbers of phagocytosed sperm cells have been quantified in the flushings of sheep uteri by the use of an electron microscope when the spermatozoa were not seen under the phase microscope (Brinsfield, Glark, Gerich \& Hawk, 1970); it is, therefore, likely that phagocytosis accounted for most of the spermatozoa that 'disappeared' within the tract.

Chang (1956) and Moyer, Legoretta, Maruta \& Henderson (1967) found large numbers of tailless sperm heads in rabbit uteri after depositing semen in the uterus, and Blandau \& Odor (1949) and Ericsson \& Baker (1966) found broken sperm cells in the reproductive tracts of the rat. In the sheep uterus, the breakage of sperm cells was increased by endogenous or exogenous oestrogen and by the presence of a plastic spiral in the uterine lumen; sperm breakage was decreased by endogenous or exogenous progesterone (Conley \& Hawk, 1970; Hawk \& Cooper, 1971).

The ligated ewes (Groups 3 and 4, Table 2) had somewhat smaller numbers of spermatozoa in their oviducts than did the ewes with open tracts, despite the far greater numbers of sperm cells which were found in the vaginae and cervices of the ligated ewes. It is possible that the presence of the ligature at the vulvovaginal junction caused partial failure of sperm transport to the oviducts. If so, the physiological basis might be somewhat similar to that which totally inhibits sperm transport after the insertion of a plastic spiral into the sheep uterus; in the latter case, sperm transport failure is apparently caused by uterine contractions being propagated towards the cervix rather than towards the oviducts (Hawk, 1970). 
Sperm cell losses in regulated ewes

The total number of spermatozoa recovered from the whole length of the tract of ewes with open reproductive tracts (Groups 1 and 2, Table 2) averaged about 2,400,000 for cyclic ewes and 59,000 for regulated ewes. The number of spermatozoa recovered intact averaged 1,085,000 for the cyclic ewes and 9000 for the regulated ewes; the smaller number of intact spermatozoa in the regulated ewes may be important because of the limitation on the number of intact spermatozoa available for transport to the oviducts during the later stages of oestrus. Quinlivan \& Robinson (1967) have suggested that the lowered fertilization rate of ewes in regulated oestrus was probably due to the fact that few spermatozoa were present in the oviducts of some of the ewes. The data in Table 2 indicate that the failure to find spermatozoa in the oviducts of a high proportion of the regulated ewes with open tracts was associated with low numbers of intact spermatozoa in the vaginae and cervices of the same ewes. The data of Quinlivan \& Robinson (1969) indicate that normal numbers of sperm cells were present in the cervices of regulated ewes $12 \mathrm{hr}$ after insemination; between 12 and $24 \mathrm{hr}$, the number of spermatozoa in the cervix decreased greatly in the regulated ewes but not in the controls.

The reproductive tracts of the regulated ewes in the present study had the capacity to cause the disappearance within the tract of more than $205 \times 10^{6}$ sperm cells and the apparent loss by drainage of at least $330 \times 10^{6}$ spermatozoa ; it is evident that a small increase in the disappearance of spermatozoa within the tract or the drainage of spermatozoa from the tract could account for the fewer numbers recovered from the regulated ewes. This phenomenon could be explained by some effect of the progestagen absorbed from the sponge or by some response of the animal to the physical presence of the sponge itself.

The results of work in progress in this laboratory suggest that, in contrast to the detrimental effects of progestagen sponges, the presence of a blank sponge in the sheep vagina until 2 days before cyclic oestrus does not decrease the numbers of spermatozoa in the vagina and cervix $24 \mathrm{hr}$ after insemination and does not interfere with sperm transport to the oviducts. The feeding of synthetic progestagens to regulate ovulation greatly decreases the numbers of sperm cells in the oviducts and uterus, but does not cause such a marked decrease in numbers of spermatozoa in the vagina, suggesting that the feeding of synthetic progestagens inhibits the normal function of sperm transport mechanisms at the regulated oestrus. Since the MAP sponges used in the present study drastically decreased the numbers of spermatozoa in the cervix and vagina, no indication could be obtained of whether sperm transport mechanisms were operating normally in these ewes. It is possible that the progestagen sponge not only causes the depletion of sperm reservoirs in the cervix and vagina but also decreases the efficiency of sperm transport mechanisms.

From the ligated tracts of regulated ewes, nearly $300 \times 10^{6}$ spermatozoa were recovered as tailless heads, about six times as many as were recovered from ligated cyclic ewes (Groups 3 and 4, Table 2). This difference indicates that the MAP sponges markedly increased the capacity of the reproductive tract to cause sperm breakage. Whether sperm breakage is an important means of sperm loss in regulated ewes with open tracts is not known, but the means in 
Table 2 indicate that higher proportions of the total sperm recovered were broken in the regulated than in the cyclic ewes (Group 1 versus Group 2). Increased sperm breakage following the use of progestagen sponges could obviously hasten the depletion of reservoirs of viable spermatozoa in the cervix and vagina.

Since oestrogen increases and progesterone decreases sperm breakage in the sheep uterus (Hawk \& Cooper, 1971), it seems unlikely that any lingering effects of progestagen from the sponges of the present experiment would intensify sperm breakage by direct action on the reproductive tract. Rather, the increased sperm breakage in regulated ewes would be consistent with the possibility that the reproductive tracts of these ewes were under greater oestrogenic influences than were the tracts of ewes in cyclic oestrus. The uteri of cattle being fed a synthetic progestagen and the uteri of luteal phase cattle both failed to remove tetracycline labelling from bull spermatozoa; however, the uteri of oestrous cattle removed tetracycline from spermatozoa, and uteri of cows in oestrus after the last progestagen feeding had an even greater capability for removing tetracycline (Lauderdale \& Ericsson, 1970). It might be relevant that considerable follicular development and signs of oestrogenic stimulation after their corpora lutea had regressed were apparent in heifers while they were still being fed a synthetic progestagen (Zimbelman \& Smith, 1966). These considerations of possible excessive oestrogenic influences on the reproductive tract of regulated animals must be balanced by the consideration that failure of sperm transport mechanisms would suggest excessive progestational influences on the tract.

\section{ACKNOWLEDGMENTS}

The authors express appreciation to Dr D. J. Bolt for helpful suggestions during the course of this study and to Dr R. G. Zimbelman and Dr J. W. Lauderdale, The Upjohn Company, Kalamazoo, Michigan, for supplying the progestagenimpregnated sponges.

\section{REFERENCES}

Blandau, R. J. \& OdoR, D. L. (1949) The total number of spermatozoa reaching various segments of the reproductive tract in the female albino rat at intervals after insemination. Anat. Rec. 103, 93.

Brinsfield, T. H., Glark, M. V., Gerich, V. \& Hawk, H. W. (1970) Disappearance and phagocytosis of sperm in sheep uteri. F. Anim. Sci. 31, 218.

Ghang, M. C. (1956) Reaction of the uterus on spermatozoa in the rabbit. Annali Ostet. Ginec. 78, 74.

Conley, H. H. \& Hawk, H. W. (1970) Intensification by intrauterine devices of sperm loss from sheep uteri. Biol. Reprod. 2, 401 .

ERIGsson, R. J. \& BAKER, V. F. (1966) Transport of oestrogens in semen to the female rat during mating and its effect on fertility. F. Reprod. Fert. 12, 381.

First, N. L., Short, R. E., Peters, J. B. \& Stratman, F. W. (1968) Transport and loss of boar spermatozoa in the reproductive tract of the sow. F. Anim. Sci. 27, 1037.

Hawk, H. W. (1970) Rapid disruption of sperm transport mechanisms by intra-uterine devices in the ewe. 7. Reprod. Fert. 23, 139.

HAWK, H. W. \& COOPER, B. S. (1971) Influence of ovarian hormones on sperm disappearance and 'breakage' in sheep uteri. J. Reprod. Fert. 27, 349.

Lauderdale, J. W. \& Ericsson, R. J. (1970) Physiological conditions affecting the ability of cattle uteri to influence the fertilizing capacity of sperm. Biol. Reprod. 2, 179. 
Moyer, D. L., Legoretta, G., Maruta, H. \& Henderson, V. (1967) Elimination of homologous spermatozoa in the female genital tract of the rabbit: a light- and electron-microscope study. F. Path. Bact. 94, 345.

Quinilvan, T. D. \& RoBinson, T. J. (1967) The number of spermatozoa in the Fallopian tubes of ewes at intervals after artificial insemination following withdrawal of SC-9880 impregnated intravaginal sponges. In: The Control of the Ovarian Cycle in the Sheep, p. 177. Ed. T. J. Robinson. Sydney University Press.

Quinlivan, T. D. \& Robinson, T. J. (1969) Numbers of spermatozoa in the genital tract after artificial insemination of progestagen-treated ewes. F. Reprod. Fert. 19, 73.

ReID, B. L. (1965) The fate of uterine spermatozoa in the mouse post coitum. Aust. F. Zool. 13, 189.

Robinson, T. J., MOORE, N. W., Holst, P. J. \& SMrTh, J. F. (1967) The evaluation of several progestagens administered in intravaginal sponges for the synchronization of oestrus in the entire cyclic Merino ewe. In: The Control of the Ovarian Cycle in the Sheep, p. 76. Ed. T. J. Robinson. Sydney University Press.

Zimbelman, R. G. \& SMrTh, L. W. (1966) Control of ovulation in cattle with melengestrol acetate. II. Effects on follicular size and activity. F. Reprod. Fert. 11, 193. 